\title{
Assessment of Follow-up and Treatment Outcomes of Eyes With Wet Age-Related Macular Degeneration (Wet AMD) for 2 Years in a Real-Life Clinical Practice Setting
}

\section{Yaş Tip Yaşa Bağlı Maküla Dejeneransı'nda (YBMD) Ranibizumab Pro Re Nata (PRN) Rejimi Benimsenen Olgularda İki Yıllık Gerçek Yaşam Sonuçlarımız}

\author{
(D) İsmail Umut Onur ${ }^{1}$, (D) Mehmet Fatih Aşula2, (1) Ulviye Yiğit ${ }^{1}$, (1) Utku Furuncuoğlu³, (D) Ozan Sonbahar ${ }^{1}$ \\ ${ }^{1}$ University of Health Sciences Turkey, Bakırköy Dr. Sadi Konuk Training and Research Hospital, Clinic of Ophthalmology \\ ${ }^{2}$ Tosya State Hospital, Clinic of Ophthalmology, Kastamonu, Turkey \\ ${ }^{3}$ Kastamonu Training and Research Hospital, Clinic of Ophthalmology, Kastamonu, Turkey
}

\begin{abstract}
Objective: The objective of this study is to assess the follow-up and treatment outcomes of eyes with wet age-related macular degeneration (wet AMD) for two years in a real-life clinical practice setting.

Methods: In total, 37 eyes of 37 patients with wet AMD treated with $0.5 \mathrm{mg}$ of intravitreal ranibizumab as needed and with at least 2 years of follow-up were retrospectively evaluated. Analyses included best-corrected visual acuity (BCVA) and central foveal thickness measurements (CFT) by optical coherence tomography at baseline, sixth month, first year, and second year along with the number of injections and follow-up visits.

Results: A total of 37 eyes of 37 patients ( 23 women and 14 men) with a mean age of $74.6 \pm 7.9$ years were evaluated in this study. The mean BCVAs were $58.1 \pm 26.7$ letters at baseline, $59.9 \pm 29.3$ letters at the sixth month, $58.8 \pm 28.9$ letters at the first year, and $59.2 \pm 28.5$ letters at the second year. No statistically significant difference in BCVA was detected among the scores at baseline, sixth month, first year, and second year $(p=0.214,0.791$, and 0.945 , respectively). The CFTs averaged $340.6 \pm 89.7 \mu \mathrm{m}$ at baseline, $316.9 \pm 87.8 \mu \mathrm{m}$ at the sixth month, $330.2 \pm 95.8 \mu \mathrm{m}$ at the first year, and $323.4 \pm 97.2 \mu \mathrm{m}$ at the second year. Only the CFT at sixth month showed a statistically significant improvement over the baseline value $(p=0.031)$.

Conclusion: Considering the number of injections and follow-up visits, along with the course of outcomes in BCVA and CFT, our real-life outcomes remained far below the outcomes reported in pivotal randomized clinical trials. However, recent papers related to real-life performance in wet AMD show similar results to those of our study.
\end{abstract}

Keywords: Wet AMD, ranibizumab, PRN, real-life outcomes

\section{öz}

Amaç: Kliniğimiz retina birimince takip edilen yaş tip yaşa bağlı maküla dejeransı (YBMD) hastalarının 2 yıllık gerçek yaşam takip ve tedavi parametrelerinin değerlendirilmesi.

Gereç ve Yöntem: Çalışma kriterlerine uygun şekilde takipte kalan ve intravitreal 0,5 mg ranibizumab tedavisi uygulanan yaş tip YBMD tanısı almış 37 hastanın 37 gözü retrospektif olarak değerlendirildi. Demografik özelliklerin yanında başlangıç, 6. ay, 1. yıl, 2. yıl en iyi düzeltilmiş görme keskinlikleri (EIDGK), optik kohorens tomografi (OKT) santral foveal kalınlık (SFK) değerlerindeki değişim ile 1. yılda ve 2. yılda gerçekleştirilebilmiş muayene ve enjeksiyon sayıları irdelendi.

Bulgular: Yirmi dördü kadın 14'ü erkek 37 hastanın yaş ortalaması 74,6 7,9 iken, görme keskinliği skoruna göre EiDGK sırası ile başlangıçta

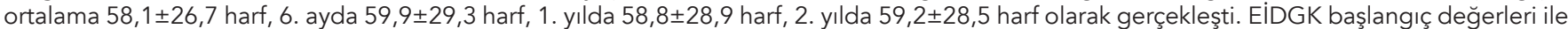
1. yıl, 2. yıl değerleri arasında istatiksel olarak anlamlı farklılık izlenmedi $(p=0,791, p=0.945)$. OKT SFK değerleri ise sırası ile başlangıçta ortalama

Address for Correspondence: Mehmet Fatih Aşula, Tosya State Hospital, Clinic of Ophthalmology, Kastamonu, Turkey Phone: +90 5324044146 E-mail: fatihasula@gmail.com ORCID ID: orcid.org/0000-0003-3856-9297 
$340,6 \pm 89,7 \mu \mathrm{m}, 6$. ayda $316,9 \pm 87,8 \mu \mathrm{m}, 1$. yılda $330,2 \pm 9,8 \mu \mathrm{m}, 2$. yılda $323,4 \pm 97,2 \mu \mathrm{m}$ olarak seyretti. OKT SFK değerlerinde 6. aydaki SFK değeri başlangıç değerine göre anlamlı ölçüde azalmış ( $p=0,031)$ olmakla beraber; 1. ve 2. yıllardaki SFK değerleri başlangıç değerlerine göre anlamlı bulunmamıştır $(p=0,594, p=0,233)$.

Sonuç: Kliniğimiz retina birimince takip/tedavi edilen gözlere uygulanan enjenksiyon sayısı ve muayene sayısı konu ile ilgili rehber niteliği taşıyan çok merkezli randomize çalışmalarda bildirilen rakamlardan düşük olarak izlenmektedir. Buna karşlık gerçek yaşam pratiğinde tedavi ve takip performansı ile 2 yıllık süreçte başlangıç görme düzeyleri ve OKT parametrelerinin en azından korunmuş olduğu görülmektedir. Bu sonuç, benzer gerçek yaşam çalışmaları ile uyumludur.

Anahtar Kelimeler: Yaş tip YBMD, ranibizumab, PRN, gerçek yaşam sonuçları

\section{INTRODUCTION}

Age-related macular degeneration (AMD) is reported as the most common cause of legal blindness that affects $10 \%-13 \%$ of adults aged above 65 years in North America, Europe, Australia and, recently, Asia (1,2). AMD imposes a crucial medical and socioeconomic burden on resources worldwide, and its incidence is expected to double by 2020 because of the greater longevity, diversification of environmental risk factors, and, in particular, the negative effects of arteriosclerosis, obesity, and smoking (3-7).

AMD is classified in two subtypes: dry and wet (or neovascular). Dry AMD is more common, whereas $80 \%$ of the patients who experience severe visual loss suffer from wet AMD $(8,9)$. Wet AMD is characterized by an abnormal growth of newly formed blood vessels by processes that are not fully understood; however, the stimulation of pathological choroidal neovascularization (CNV) appears to involve the vascular endothelial growth factor (VEGF) (10). VEGF blockade is an effective treatment in patients affected by neovascular AMD (11,12).

CNV subtypes observed in wet-type AMD are characterized as type 1 (occult), type 2 (classical), type 3 (retinal angiomatous proliferation), and polypoid choroidal vasculopathy (PCV) lesions (13). The inhibition of VEGF-A has been reported to mitigate the pathophysiological process of $A M D$, reverse the retinal damage partially, and sustain the neurosensory function in most eyes with neovascular AMD $(11,14)$. One potent inhibitor is ranibizumab (Lucentis, Novartis, Switzerland), which is a recombinant, humanized, and monoclonal VEGF antibody specifically developed for use in the eye.

Ranibizumab enhances angiogenesis and vascular permeability by binding and inactivating all the isoforms of VEGF-A for suppressing the formation of CNV lesions $(15,16)$. This drug has undergone multi-centered, randomized, and prospective trials for licensing, and these studies have reported similar responses or no statistically significant differences for monthly application, three consecutive loadings, and treat-as-needed or treat-extend protocols (12,17-19). However, a significant difference could be anticipated between the "achievable" results of reallife practice and the "maximized" results of these previous trials conducted under ideal conditions.

In this context, the objective of this study is to present the anatomical and functional real-life outcomes of eyes with AMD upon treatment with a "treat-as-needed" regimen following three consecutive monthly loading doses [pro re nata (PRN)] during a two-year course of injections and follow-ups.

\section{METHODS}

The study was conducted in accordance with the tenets of the Declaration of Helsinki and after receiving the approval of the The study were approved by the Bakırköy Dr. Sadi Konuk Training and Research Hospital of Local Ethics Committee (Protocol number: 2017/68). Informed consent was obtained from all individual participants included in the study.

The records of eyes with AMD treated with intravitreal ranibizumab between October 2013 and October 2016 and followed up for 24 months in our tertiary eye clinic were retrospectively reviewed in this study. Patients were enrolled if they had developed CNV because of AMD and had not been treated previously anywhere else. Only the eye with the lower visual acuity was selected in the cases of bilateral involvement. The eyes of patients aged under 50 years; eyes having any comorbidity such as diabetic retinopathy, retinal vein occlusion, inflammatory eye disease, or previous intraocular surgery other than cataract surgery; or eyes with optical media obscuring the visual axis were excluded from the study. In addition, eyes with suspicious possible distinctive diagnosis, such as high myopia, choroid rupture, and angioid streak that could lead to secondary CNV, were also excluded from this study.

The best-corrected visual acuities (BCVAs) of the eyes were converted to the Early Treatment Diabetic Retinopathy Study (ETDRS) letter scores. Intraocular pressure measurements, biomicroscopic anterior segment examination findings, and dilated fundus findings of all eyes were reviewed and entered onto data forms. 
Central foveal thickness (CFT) measurements obtained by the optical coherence tomography (OCT) (RTVue Optovue Inc., Fremont, California, USA) MM5 protocol were assessed. Importantly, the CNV subtypes were identified according to fundus fluorescein angiography (FFA) and OCT (Raster scans) images.

In our practice, $0.5 \mathrm{mg} / 0.05 \mathrm{~mL}$ of intravitreal ranibizumab (Lucentis, Novartis, Switzerland) was injected following oral/written consent before each session. Patients were treated with a PRN regimen following three loading doses administered one month apart. If stabilization was not achieved, then the ranibizumab injection was repeated monthly in the cases with a visual acuity reduction of five letters or more, the persistence of intraretinal or subretinal fluid on OCT, or the detection of an increase in macular thickness or hemorrhage. The patients were strictly instructed to come to treatment sessions and follow-ups at intervals not exceeding 4-6 weeks.

The data for the eyes followed up for two years after three consecutive loading doses and the PRN regime were assessed. In addition to the anatomic-functional parameters, such as at baseline, sixth month ( \pm 1 month), first year ( \pm 2 months), and second year ( \pm 2 months) BCVA and CFT, other performance parameters obtained in reallife conditions, such as the time from the first visit to the FFA imaging, the time from the diagnosis/treatment decision to the first intravitreal injection, the completion time of the first three loading doses, the total number of injections, and the total number of follow-up examinations achieved were also considered. The mean, standard deviation, median, lowest and highest values, frequencies, and ratios were used in the descriptive statistics of the data. The distribution of variables was evaluated with the Kolmogorov-Smirnov test, followed by the Wilcoxon test for analyzing the dependent quantitative data. A value of $p<0.05$ was considered statistically significant.

\section{Statistical Analyses}

The SPSS 22.0 (SPSS Inc. Chicago, USA) software was used in the analysis.

\section{RESULTS}

Data were evaluated from the 37 eyes of 37 patients with wet AMD who received ranibizumab injections and remained on regular follow-ups for 2 years between October 2013 and October 2016. Of the 37 patients, 14 (38\%) were males and $23(62 \%)$ were females. The mean age was $74.6 \pm 7.9$ years. The CNV subtypes comprised type 1 lesions in 21 eyes (57\%), type 2 lesions in 11 eyes (30\%), type 3 lesions in 3 eyes (8\%), and PCV (5\%) in 2 eyes. The mean duration between the patients' first examinations to FFA imaging was $40.5 \pm 64.1$ days (0-283). The consecutive and monthly administration of the first three loading doses per protocol were completed in a mean of $18.8 \pm 12.5$ weeks. During the course of follow-ups, a mean of $3.3 \pm 1.5$ injections were administered at the end of the first year and $5.0 \pm 2.5$ injections were administered at the end of the second year. The first three loading dose targets per protocol could not be reached in eight patients at the end of the first year, and that number dropped to two patients at the end of the second year. The mean number of visits at the end of the first and second years were 5.9 \pm 2.2 and $12.5 \pm 7.4$, respectively.

The ETDRS letter scoring indicated a mean BCVA of $58.1 \pm 26.7$ letters before the injection, $59.9 \pm 29.3$ letters at the sixth month after treatment, $58.8 \pm 28.9$ letters at the first year, and $59.2 \pm 28.5$ letters at the end of the second year. The mean BCVA did not differ significantly from baseline to the scores at the sixth month, first year, and second year $(p=0.214,0.791$, and 0.945$)$. Table 1 summarizes the changes in BCVA.

In total, 9 eyes (24\%) lost 15 letters or more in the first year and $13(35 \%)$ lost 15 letters or more in the second year. Moreover, 8 eyes (21\%) gained 15 letters or more in the first year and $10(27 \%)$ gained 15 letters or more in the second year.

The OCT measurements indicated a mean CFT of $340.6 \pm 89.7 \mu \mathrm{m}$ at baseline before treatment, $316.9 \pm 87.8$ $\mu \mathrm{m}$ at the sixth month after treatment, $330.2 \pm 95.8 \mu \mathrm{m}$ at the first year, and $323.4 \pm 97.2 \mu \mathrm{m}$ at the second year. The only significant decrease in CFT as compared to the baseline was observed at 6 months $(p=0.031)$. In the first and second years, the reductions in SFT were not statistically significant as compared to the baseline level $(p=0.594,0.233)$. Table 2 summarizes the changes in the CFT over time.

\begin{tabular}{lccll}
\hline \multicolumn{5}{l}{ Table 1. Changes in BCVA (ETDRS Letters) } \\
\hline & Q1-Q3 & Med & Mean \pm SD & p \\
\hline Baseline & $43-80$ & 65 & $58.1 \pm 26.7$ & \\
\hline Sixth month & $35-87$ & 59 & $59.9 \pm 29.3$ & $0.214^{w}$ \\
\hline First year & $35-89$ & 59 & $58.8 \pm 28.9$ & $0.791^{w}$ \\
\hline Second year & $35-85$ & 59 & $59.2 \pm 28.5$ & $0.945^{w}$ \\
\hline
\end{tabular}

Wilcoxon test, Med: Median, SD: standard deviation, Q1, Q3: quartile 1, quartile 3, BCVA: Best-corrected visual acuity

\section{DISCUSSION}

The widespread use of ranibizumab in routine clinical practice has raised concerns regarding the efficacy that can 
Table 2. Changes in CFT $(\mu \mathrm{m})$

\begin{tabular}{|c|c|c|c|c|}
\hline & Q1-Q3 & Med & Mean \pm SD & $p$ \\
\hline Baseline & $296-377$ & 340 & $340.6 \pm 89.7$ & \\
\hline Sixth Month & $264-348$ & 301 & $316.9 \pm 87.8$ & $0.031^{w}$ \\
\hline First Year & $266-389$ & 299 & $330.2 \pm 95.8$ & $0.594^{w}$ \\
\hline Second Year & $258-357$ & 309 & $323.4 \pm 97.2$ & $0.233^{w}$ \\
\hline
\end{tabular}

be achieved in real-life practice. In recent years, a number of studies have shown that the results obtained with ranibizumab in clinical practice do not correspond well with the results reported in company-sponsored multi-centered, randomized phase 3 clinical trials $(20,21)$ For example, the Kaiser et al. (17) and Brown et al. (12) studies, which used fixed monthly treatment regimens, reported the gains of +6.6 and +10.7 letters, respectively, as compared to the baseline at the end of 2 years. The Ho et al. (22) study, which applied three consecutive monthly loading doses plus a PRN regimen, reported the gains of +7.9 letters after 2 years and this result was similar to the results obtained with a fixed monthly treatment regimen. The comparison of a fixed monthly treatment regimen with one comprising three consecutive monthly loading doses plus PRN regimen itself in the CATT (23) and HARBOR studies revealed a difference of +1.2 letters in favor of the monthly regimen after 2 years, but the difference was not statistically significant.

By contrast, significant differences were reported for the results of the multi-centered Lalwani et al. (18) and Ho et al. (22) randomized trials that adopted the PRN treatment regimen, in agreement with the results of our real-life clinical practice values obtained at the end of the second year after providing the same treatment regimen to 37 patients. The comparison of the pre-treatment baseline results and the results at the end of the first year in the Lalwani et al. (18) and $\mathrm{Ho}$ et al. (22) studies revealed a mean letter gain in the BCVA of +11.1 letters and +8.2 letters, respectively. By contrast, in our study, this difference was only +0.7 letters. At the end of the second year, the letter gains in the Lalwani et al. (18) and Ho et al. (22) studies were +9.3 and +7.9 letters, respectively, whereas this number was +1.1 letters in our study.

The Lalwani et al. (18) and Ho et al. (22) trials reported the rates of $35 \%$ and $30.2 \%$ for cases that gained 15 letters and above in BCVA in the first year, whereas that rate was $21.6 \%$ in our study. Similarly, in the second year, the number of cases that gained 15 letters or more were $43 \%$ and $33.1 \%$ in the Lalwani et al. (18) and Ho et al. (22) studies, respectively, whereas it was $27 \%$ in our study. In the first year, the prevention of the loss of more than 15 letters in BCVA was $95 \%$ and $94.5 \%$ in the Lalwani et al. (18) and Ho et al. (22) trials, respectively, but only $75.6 \%$ in our study. In the second year, these values were $97.5 \%$ and $90.9 \%$ for the Lalwani et al. (18) and Ho et al. (22) studies, respectively, but it was only $64.8 \%$ in our study.

The comparison of the pre-treatment baseline values in OCT/ CFT measurements revealed a significant decrease only in the sixth month in our study, with no significant decreases below baseline in the OCT/CFT measurements performed in the first and second years. However, the Lalwani et al. (18) and Ho et al. (22) studies reported decreases in SFT of 215 $\mu \mathrm{m}$ and $172 \mu \mathrm{m}$, respectively, in the second year.

The examination of the number of injections that could be performed in our study identified eight patients for whom the first three consecutive loading doses could not be completed in the first year; this number dropped to two patients in the second year. In our study, a mean of 3.3 injections were performed in the first year and a mean of 5.0 at the end the second year. By contrast, the reported average number of injections for the first year in the multicentered, randomized Lalwani et al. (18) and Ho et al. (22) trials, which used the same treatment regimen as in our study, were 5.6 and 7.7, respectively, in the first year and 9.9 and 13.3, respectively, in the second year. The Lalwani et al. (18) and Ho et al. (22) studies requested strict monthly follow-ups, even if no injections were administered. We achieved a mean of 5.9 visits in the first year and 12.5 visits in the second year in our study.

The accumulation of clinical practice studies reporting the outcomes of ranibizumab treatments for wet AMD is now revealing gaps between the results reported in the multicentered, randomized licensing trials and those obtained in the real-life studies. For example, the observational phase 4 Kaiser et al. (17) study, which evaluated the application of ranibizumab in clinical practice, reported an average letter loss of -1.3 , whereas the mean number of injections was 6.2 (4.4 in the first year) at the end of the second year. In the series by Özkan et al. (24) in which they adopted a PRN protocol with two years of follow-up, the final level of vision was reported to be same as the initial baseline level, whereas the average number of injections was 5.8 (first year). The series by Chavan et al. (25) conducted according to the UK-based PRN dosing regimen, reported a mean letter loss of -2.3 letters at the end of the second year with a mean number of 9.9 injections. Another study by Frennesson and Nilsson (26) conducted according to the Swedish-based PRN dosing regimen, reported an average letter gain of +1 letter at the end of the second year, whereas the average 
number of injections was 7.9. A meta-analysis of 20 studies examined by Chong (20) reported a first year letter gain ranging from 2.0 to +5.5 and a weighted mean gain of +1.95 letters for the real-life results of ranibizumab application in wet AMD. At the end of the first year, the rate of cases that gained 15 or more letters was $19 \pm 7.5 \%$, whereas the rate of cases that lost 15 or fewer letters was $89 \pm 6.5 \%$ (74.4\%97.4\%) (20). The number of injections varied between 4.2 and 7.5 at the end of the first year, with a mean value of $5.5 \pm 0.8(20)$.

The comparison of the number of injections and vision outcomes of this retrospective two-year real-life study with the results reported by the company-sponsored, multi-centered, and randomized trials reveal a significant difference. However, this difference is no longer significant when the results are compared with the results of similar real-life studies. In real-life studies, other parameters that influence the performance and outcomes can have pivotal roles; these can include the quality and performance of the health care providers and third parties, the quality of patient-physician communication, and the sociocultural features of the patients. In our study, the time from the first visit to FFA was clearly so long that it might have retarded the time to start the injections. However, FFA and OCT evaluations are prerequisites for the reimbursement process by our social security institution (SGK). Increasing patient loads, insufficient hospital conditions, and insufficient staff may also have negative effects on access to regular followup visits, thereby reducing the number of injections. The preferences of the physicians or patients and the course of the disease dictate the flexibility in the protocols. However, similar problems are foreseen in all countries and institutions.

The main limitations of this study are its retrospective design, the inclusion of lower baseline BCVA scored eyes as finger counting, and a small number of patients. These all may explain why the results of our study were persistently lower than the values reported in company-sponsored, multi-centered trials. In addition, a number of patients dropped out of the study during treatment and follow-ups from the FFA stage.

Regardless of the current follow-up and treatment protocols, the treatment follow-up cycle places a serious financial and moral burden on the patients. When the expression "real-life results" is defined in a broader sense to cover all patients unable to continue treatment and follow-ups, the outcomes are likely to show a greater underperformance than anticipated.

\section{CONCLUSION}

In summary, an increase in the number of studies reporting "real-life" results by relevant clinics and physicians for the treatment of wet AMD would enable the exposure of the achievable treatment and follow-up performance related to this disease. The consideration of real-life results could also force the pharmaceutical industry to expedite its work in developing new drug formulations that require fewer injections. Alternatively, the development of customized treatment and follow-up protocols may be possible that consider AMD risk factors, such as the characteristics and course of CNV lesions on the diseased eye, the involvement of fellow eye, and so on. This would allow fewer followup visits and injections in low-risk eyes and more frequent follow-ups and injections in high-risk eyes, along with an increased patient motivation.

\section{Ethics}

Ethics Committee Approval: The study was conducted in accordance with the tenets of the Declaration of Helsinki and after receiving the approval of the institutional ethical review board (approval number: 2017/68).

Informed Consent: Informed consent was obtained from all individual participants included in the study.

\section{Authorship Contributions}

Surgical and Medical Practices: I.U.O., U.Y., U.F., O.S., M.F.A., Concept: I.U.O., U.Y., U.F., M.F.A., Design: I.U.O., U.Y., M.F.A., O.S., Data Collection or Processing: I.U.O., U.Y., U.F., O.S., Analysis or Interpretation: : I.U.O., U.Y., M.F.A., U.F., O.S., Literature Search: I.U.O., U.Y., M.F.A., U.F., O.S., Writing: I.U.O., U.Y., M.F.A.

Conflict of Interest: No conflict of interest was declared by the authors.

Financial Disclosure: The authors declared that this study received no financial support.

\section{REFERENCES}

1. Smith W, Assink J, Klein R, Mitchell P, Klaver CC, Klein BE, et al. Risk factors for age-related macular degeneration: Pooled findings from three continents. Ophthalmology 2001;108:697-704.

2. Kawasaki R, Yasuda M, Song SJ, Chen SJ, Jonas JB, Wang JJ, et al. The prevalence of age-related macular degeneration in Asians: a systematic review and meta-analysis. Ophthalmology 2010;117:921-7.

3. Friedman DS, O'Colmain BJ, Muñoz B, Tomany SC, McCarty C, de Jong PT, et al. Prevalence of age-related macular degeneration in the United States. Arch Ophthalmol 2004;122:564-72.

4. Seddon JM, Willett WC, Speizer FE, Hankinson SE. A prospective study of cigarette smoking and age-related macular degeneration in women. JAMA 1996;276:1141-6. 
5. Seddon JM, Cote J, Davis N, Rosner B. Progression of age-related macular degeneration: association with body mass index, waist circumference, and waist-hip ratio. Arch Ophthalmol 2003;121:78592.

6. Klein R, LiX, Kuo JZ, Klein BE, Cotch MF, Wong TY, et al. Associations of candidate genes to age-related macular degeneration among racial/ethnic groups in the multi-ethnic study of atherosclerosis. Am J Ophthalmol 2013;156:1010-20.e1.

7. Gemmy Cheung CM, Li X, Cheng CY, Zheng Y, Mitchell P, Wang $\mathrm{JJ}$, et al. Prevalence and risk factors for age-related macular degeneration in Indians: a comparative study in Singapore and India. Am J Ophthalmol 2013;155:764-73.

8. Augood CA, Vingerling JR, de Jong PT, Chakravarthy U, Seland J Soubrane G, et al. Prevalence of age-related maculopathy in older Europeans: the European Eye Study (EUREYE). Arch Ophthalmol 2006;124:529-35.

9. Ferris FL 3rd, Fine SL, Hyman L. Age-related macular degeneration and blindness due to neovascular maculopathy. Arch Ophthalmol 1984;102:1640-2.

10. Kliffen M, Sharma HS, Mooy CM, Kerkvliet S, de Jong PT. Increased expression of angiogenic growth factors in age-related maculopathy. Br J Ophthalmol 1997;81:154-62.

11. Rosenfeld PJ, Brown DM, Heier JS, Boyer DS, Kaiser PK, Chung $\mathrm{CY}$, et al. . Ranibizumab for neovascular age-related macular degeneration. N Engl J Med 2006;355:1419-31.

12. Brown DM, Michels M, Kaiser PK, Heier JS, Sy JP, lanchulev T, et al. Ranibizumab versus verteporfin photodynamic therapy for neovascular age-related macular degeneration: Two-year results of the ANCHOR study. Ophthalmology 2009;116:57-65.e5.

13. Farecki ML, Gutfleisch M, Faatz H, Rothaus K, Heimes B, Spital G, et al. Characteristics of type 1 and 2 CNV in exudative AMD in OCTAngiography. Graefes Arch Clin Exp Ophthalmol 2017;255:913-21.

14. Brown DM, Kaiser PK, Michels M, Soubrane G, Heier JS, Kim RY, et al. Ranibizumab versus verteporfin for neovascular age-related macular degeneration. N Engl J Med 2006;355:1432-44.

15. Blick SK, Keating GM, Wagstaff AJ. Ranibizumab. Drugs 2007;67:1199-206.

16. Kenneth TE, Kertes PJ. Ranibizumab in neovascular age-related macular degeneration. Clin Interv Aging 2006;1:451-66.
17. Kaiser PK, Blodi BA, Shapiro H, Acharya NR; MARINA Study Group. Angiographic and optical coherence tomographic results of the MARINA study of ranibizumab in neovascular age-related macular degeneration. Ophthalmology 2007;114:1868-75.

18. Lalwani GA, Rosenfeld PJ, Fung AE, Dubovy SR, Michels S, Feuer $W$, et al. A variable-dosing regimen with intravitreal ranibizumab for neovascular age-related macular degeneration: year 2 of the PrONTO Study. Am J Ophthalmol 2009;148:43-58.e1.

19. Gupta OP, Shienbaum G, Patel AH, Fecarotta C, Kaiser RS, Regillo $\mathrm{CD}$. A treat and extend regimen using ranibizumab for neovascular age-related macular degeneration clinical and economic impact. Ophthalmology 2010;117:2134-40.

20. Chong V. Ranibizumab for the treatment of wet AMD: a summary of real-world studies. Eye (Lond) 2016;30:270-86.

21. Pagliarini S, Beatty S, Lipkova B, Perez-Salvador Garcia E, Reynders S, Gekkieva M, et al. A 2-Year, Phase IV, Multicentre, Observational Study of Ranibizumab $0.5 \mathrm{mg}$ in Patients with Neovascular AgeRelated Macular Degeneration in Routine Clinical Practice: The EPICOHORT Study. J Ophthalmol 2014;2014:857148.

22. Ho AC, Busbee BG, Regillo CD, Wieland MR, Van Everen SA, Li Z, et al. Twenty-four-month efficacy and safety of $0.5 \mathrm{mg}$ or $2.0 \mathrm{mg}$ ranibizumab in patients with subfoveal neovascular age-related macular degeneration. Ophthalmology 2014;121:2181-92.

23. CATT Research Group, Martin DF, Maguire MG, Ying GS, Grunwald $J E$, Fine SL, et al. Ranibizumab and bevacizumab for neovascular age-related macular degeneration. N Engl J Med 2011;364:1897908

24. Özkan GÜ, Ünlü N, Acar MA, Hazırolan D, Yalnız ZA, Örnek F. Yaşa Bağlı Maküla Dejeneresansında Ranibizumab Tedavisinin Uzun Dönem Sonuçları. Ret-Vit 2013;21:178-82.

25. Chavan R, Panneerselvam S, Adhana P, Narendran N, Yang Y. Bilateral visual outcomes and service utilization of patients treated for 3 years with ranibizumab for neovascular age-related macular degeneration. Clin Ophthalmol 2014;8:717-23.

26. Frennesson $\mathrm{Cl}$, Nilsson SE. A three-year follow-up of ranibizumab treatment of exudative AMD: impact on the outcome of carrying forward the last acuity observation in drop-outs. Acta Ophthalmol 2014;92:216-20. 